\title{
SPUD qPCR Assay Confirms PREXCEL-Q Software's Ability to Avoid qPCR Inhibition
}

\author{
J.M. Gallup*, F.B. Sow, A. Van Geelen \\ and M.R. Ackermann
}

Department of Veterinary Pathology, College of Veterinary Medicine, lowa State University, Ames, lowa 50011-1250, USA

\begin{abstract}
Real-time quantitative polymerase chain reaction is subject to inhibition by substances that co-purify with nucleic acids during isolation and preparation of samples. Such materials alter the activity of reverse transcriptase (RT) and thermostable DNA polymerase enzymes on which the assay depends. When removal of inhibitory substances by column or reagent-based methods fails or is incomplete, the remaining option of appropriately, precisely and differentially diluting samples and standards to non-inhibitory concentrations is often avoided due to the logistic problem it poses. To address this, we invented the PREXCEL-Q software program to automate the process of calculating the non-inhibitory dilutions for all samples and standards after a preliminary test plate has been performed on an experimental sample mixture. The SPUD assay was used to check for inhibition in each PREXCEL-Q-designed qPCR reaction. When SPUD amplicons or SPUD ampliconcontaining plasmids were spiked equally into each qPCR reaction, all reactions demonstrated complete absence of qPCR inhibition. Reactions spiked with $\sim 15,500$ SPUD amplicons yielded $\mathrm{a}_{\mathrm{q}}$ of $27.39 \pm 0.28$ (at $\sim 80.8 \%$ efficiency), while reactions spiked with $\sim 7,750$ SPUD plasmids yielded a $\mathrm{C}_{\mathrm{q}}$ of $23.82 \pm 0.15$ (at $\sim 97.85 \%$ efficiency). This work demonstrates that PREXCEL-Q sample and standard dilution calculations ensure avoidance of $\mathrm{QPCR}$ inhibition.
\end{abstract}

\section{Introduction}

In recent years, although qPCR has garnered the reputation as the foremost quantitative technique for exploring gene expression, evaluating pathogen load, detecting single nucleotide polymorphisms for allelic discrimination analysis and analyzing miRNA and gene copy numbers, the quality of its performance is altered by inhibitory substances or conditions. Inhibitory substances are introduced into the tested samples by the method of isolation, the type of sample used for nucleic acid isolation, as well as other manipulations preceding qPCR (such as phenol-chloroform precipitation, sample concentrating methods and nuclease treatments) (Bustin, 2008). To minimize inhibitory biological material carryover into samples due to the method of isolation, various companies have offered different columnbased purification kits, depending on the type of sample from which the nucleic acids are to be extracted (Wilson, 1997; Bustin, 2003; Bustin, 2005; Bustin, 2008; Bustin et

*Corresponding author: Email: eag@iastate.edu al., 2009). For instance, Qiagen offers several varieties of olumns for RNA, DNA or viral RNA or DNA isolation, and $\mathrm{PAXgene} \mathrm{TM}^{\mathrm{TM}}$ technology for blood samples and $\mathrm{MO} \mathrm{BIO}$ Laboratories has developed a line of products which remove inhibitory material from DNA that has been extracted from a variety of biological sources. Currently, there are no simple effective solutions for high-throughput extractions of (e.g.) plant leaf DNA, and for this and other sample types, many methods require multiple steps and additional expensive materials. Older methods are laborious, and kits based on spin columns are expensive and are often not designed with high-throughput potential in mind. In addition, column-based methods often yield DNA or RNA samples that still contain inhibitory polyphenolics and polysaccharides - making such nucleic acid isolates unsuitable for PCR amplification.

The challenge of eradicating qPCR inhibition has persisted as a main problem with the assay since its inception. According to a recent survey of working practices among 100 qPCR users, 94\% choose to deal with inhibition by ignoring it entirely (Bustin, 2005; Nolan et al., 2006). This represents one of the most serious and persistent deficiencies in GPCR which needs to be responsibly addressed (Bustin et al., 2005; Nolan and Bustin, 2009; Bustin et al., 2009). Some of the materials capable of inhibiting reverse transcriptase (RT) and/or DNA-dependent DNA polymerase (e.g. Taq and others) have been identified, while many of them remain as yet unknown. Too much RNA and too much DNA loaded into the reactions themselves have been demonstrated to entirely shut down the RT and/ or PCR phases of the qPCR (Gallup et al., 2006). Outside of this, substances such as IgG, porphyrin, heme, fat, heparin, humic and tannic acids, polyphenolics (including tannin), dextran sulfate, $\mathrm{Ca}^{+2}$, polysaccharides and various proteins are thought to be among the known culprits of unwanted qPCR inhibition (Tichopad et al., 2004; Gallup et al., 2006; Gallup et al., 2008). Succinctly, if a target (quantification cycle) $\mathrm{C}_{\mathrm{q}}$ value can appear anywhere from 13 to 50 on account of varying degrees of inhibition alone, it is always important to examine and/or eliminate inhibition from qPCR (Bustin, 2005; Nolan et al., 2006; Gallup et al., 2006; Bustin, 2008).

Since no method is entirely effective at removing inhibitory substances from all samples, once a method of nucleic acid sample isolation and subsequent $\mathrm{qPCR}$ have been worked out, testing for the presence of inhibition in each sample is necessary since every sample (even from the same biological source material) can still harbor differing degrees of inhibitory material. To this end, the SPUD assay was developed (Nolan et al., 2006). The SPUD assay utilizes a synthetic amplicon based on a potato sequence in conjunction with a 6FAM-TAMRA hydrolysis probe and associated primers to amplify the SPUD sequence during qPCR (this would most likely work in a SYBR Green-based qPCR format, but it has not yet been tested as such). The SPUD amplicon is spiked in equally into all samples and standards preceding $\mathrm{GPCR}$, and, in the presence 
of inhibition, $\mathrm{qPCR}$ reactions will demonstrate higher $\mathrm{C}_{\mathrm{q}}$ values for the SPUD amplicon than will uninhibited reactions (Nolan et al., 2006; Nolan and Bustin, 2009). PREXCEL-Q is a qPCR software program that, among its other functions, identifies dilution parameters for all samples and standards that avoid qPCR-inhibitory phenomena. The SPUD assay was thus used in this study to critically test and corroborate the reported ability of the PREXCEL-Q program to avoid inhibition in qPCR samples and standards (Grubor et al., 2004; Gallup et al., 2005; Gallup et al., 2006; Kawashima et al., 2006; Lazic et al., 2007; Gallup et al., 2008; Olivier et al., 2009; Sow et al., 2009; Sponseller et al., 2009).

\section{Materials and Methods}

\section{RNA isolation}

In this study, we set out to examine the presence or absence of inhibition in sheep lung total RNA isolates subjected to one-step qPCR (using Invitrogen's SuperScript ${ }^{\mathrm{TM}}$ III Platinum ${ }^{\circledR}$ One-Step quantitative RT-PCR System with ROX kit, Cat. No. 11745) using sample and standard dilutions calculated by the PREXCEL-Q software program (Gallup et al., 2006; Gallup et al., 2008; Sow et al., 2009). Total RNA was isolated from twelve lamb lung samples as follows: 1 to $3 \mathrm{~g}$ of lung (stored immediately at $-80^{\circ} \mathrm{C}$ after being flash-frozen in cryovials in liquid nitrogen post-necropsy) were initially weighed and then homogenized (in $50 \mathrm{ml}$ conical centrifuge tubes) for 30 seconds in $3 \mathrm{ml}$ of QIAzol reagent (Qiagen) using an Omni TH homogenizer (Omni International). A small portion of each resulting homogenate was then further diluted with QIAzol to obtain secondary sample slurries that were all $\sim 0.091 \mathrm{~g}$ tissue per $\mathrm{ml}$. These secondary slurries were briefly vortexed, allowed to sit for 5 minutes, and $200 \mu \mathrm{l}$ nuclease-free chloroform (Fisher) was added to each, shaken vigorously for 15 seconds, allowed to sit for 3 minutes at room temperature, and then spun at $12,000 \times g$ for 10 minutes at $4^{\circ} \mathrm{C}$. The top, aqueous layers were transferred into fresh $1.6-\mathrm{ml}$ microfuge tubes (MidSci) already containing $500 \mu \mathrm{l}$ nuclease-free 2-propanol (Fisher). Samples were briefly vortexed, and allowed to sit at room temperature for 10 minutes. This was followed by centrifugation at $16,300 \times g$ for 15 minutes at $4^{\circ} \mathrm{C}$. The 2-propanol was discarded and the pellets obtained were washed twice with pre-cooled $\left(-20^{\circ} \mathrm{C}\right) 75 \%$ nuclease-free ethanol, centrifuging at $12,000 \times g$ for 10 minutes at $4^{\circ} \mathrm{C}$ after each wash. The ethanol washes were carefully pouredoff, and pellets were allowed to air-dry under a fume hood for $\sim 30$ minutes. $170 \mu$ l nuclease-free water (Ambion) was added to each pellet, samples were vortexed briefly and then heated to $65^{\circ} \mathrm{C}$ for 5 minutes to aid in RNA dissolution. $70 \mu \mathrm{l}$ of each $(170 \mu \mathrm{l})$ sample isolate was then subjected to (Ambion) TURBO-DNase treatment which was carried out in $200 \mu \mathrm{l}$ thin-walled PCR tubes (MidSci). Each $100 \mu \mathrm{l}$ DNase treatment reaction contained: $70 \mu \mathrm{INNA}$ sample, $10 \mu \mathrm{l}$ 10X TURBO DNase buffer and $20 \mu$ I TURBO DNase $(2 \mathrm{U} / \mu \mathrm{l})$ enzyme. Once assembled, all DNase-treatment reactions were briefly vortexed and spun down, then incubated for 30 minutes at $37^{\circ} \mathrm{C}$ in a Perkin Elmer GeneAmp 2400 thermocycler. Tubes were removed from the thermocycler and $10 \mu \mathrm{l}$ of the TURBO Inactivation Reagent suspension was added to each $100 \mu \mathrm{l}$ reaction and tubes were then vortexed every 10 seconds for the next 2 minutes at room temperature (to keep the Inactivation Reagent suspended). This was followed by a 3-minute, $10,000 \times g$ centrifugation at room temperature (to pellet the Inactivation Reagent) after which $80 \mu \mathrm{l}$ was carefully removed from the very top of each final $110 \mu \mathrm{l}$ DNase-treatment reaction. These $80 \mu \mathrm{l}$ DNase-treated sample aliquots were then diluted 1:10 in fresh nuclease-free $1.6 \mathrm{ml}$ tubes (MidSci) by the addition of $708 \mu \mathrm{l}$ Ambion nuclease-free water and $12 \mu \mathrm{l}$ of RNase inhibitor (RNaseOUT'M , Invitrogen, Cat. No. 10777-019).

\section{Custom NanoDrop zeroing buffer}

A water sample was prepared in tandem with the RNA samples and subjected to the exact same DNase-treatment regimen as the RNA samples for the purpose of creating the proper zeroing (blanking) buffer for NanoDrop assessments. Prior to measuring samples by NanoDrop, each sample was diluted 1:3.2 (50 $\mu$ l sample $+109 \mu$ l nuclease-free water). NanoDrop $\mathrm{ng} / \mu \mathrm{l}$ assessments were converted to their corresponding RNA $A_{260 n m}$ readings by dividing each $\mathrm{ng} / \mu \mathrm{l}$ value by the RNA extinction coefficient, $40 \mu \mathrm{g} /$ $\mathrm{mL} / 1$ o.d. @ 260nm·cm. The entire sample dilution factor (since resolubilization in $170 \mu$ l of nuclease-free water) was thus calculated to be 1:50 for each sample at the time of NanoDrop assessment (e.g. DNase treatment resulted in sample dilution of $\sim 0.64$, and subsequent dilution with water and RNaseOUT'тм resulted in another 0.1 dilution, and the final, additional $\sim 1: 3.2$ dilution (preceding NanoDrop readings) yielded an overall sample dilution of 0.02 , or "1:50"). Sample purity was also determined by absorbance readings at 260 and $280 \mathrm{~nm}$, and all samples demonstrated purity $\left(A_{260: 280 \mathrm{~nm}}\right)$ ratios of 2.0 or higher (Table 1$)$.

Previously-established PREXCEL-Q parameters for sheep lung RNA isolates used in qPCR using the "Stock I approach"

PREXCEL-Q was used previously with numerous mRNA targets in sheep lung total RNA isolates used to determine the valid working ranges for all samples and standards. (Gallup et al., 2005; Gallup et al., 2006; Olivier et al., 2009; Sow et al., 2009). Standards prepared from sample mixtures

Table 1. 1:50 sample RNA NanoDrop readings and purity ratios. Samples B, C, F, H and J were used in this study since they represented the widest range of sample readings for this sample set.

\begin{tabular}{|c|c|c|}
\hline Sample I.D. & $\underline{260}$ & $260 / 280$ \\
\hline$A$ & $\overline{0.76}$ & 2.18 \\
\hline B & 0.79 & 2.2 \\
\hline C & 0.55 & 2.25 \\
\hline $\mathrm{D}$ & 0.65 & 2.23 \\
\hline$E$ & 0.84 & 2.19 \\
\hline $\mathrm{F}$ & 0.95 & 2.03 \\
\hline$G$ & 0.76 & 2.22 \\
\hline $\mathrm{H}$ & 0.86 & 2.17 \\
\hline I & 0.74 & 2.21 \\
\hline$J$ & 0.71 & 2.22 \\
\hline K & 0.83 & 2.19 \\
\hline$L$ & 0.92 & 2.16 \\
\hline
\end{tabular}


(called "Stock l") appeared to behave without qPCR inhibition when used at dilutions of 1:500 and above. Therefore, when setting up the qPCR for this study, standards were prepared in the range of $1: 500$ to $1: 8000$, representing a range of 3.12 $\mathrm{ng} / \mu \mathrm{l}$ to $0.195 \mathrm{ng} / \mu \mathrm{l}$ in-well. Individual samples were diluted to $8.12 \mathrm{ng} / \mu \mathrm{l}$ and $6 \mu \mathrm{l}$ of each sample was added per 25 $\mu$ reaction volume. All RNA samples were thus $1.95 \mathrm{ng} / \mu \mathrm{l}$ per well during qPCR assessment for the presence of three targets: ovine intercellular adhesion molecule-1 (ovine ICAM-1), SPUD 101 bp amplicon (Nolan et al., 2006), and the very same SPUD $101 \mathrm{bp}$ amplicon cloned into a doublestranded DNA plasmid construct made by Integrated DNA Technologies in Coralville, lowa) (pIDTSMART-KAN, IDT).

Primers, probes, targets, amplicon and plasmid The ovine ICAM-1 primers and probe (synthesized by $A B I$ ) were as follows:

ICAM-1 Fwd primer: 5'-CAAGGGCTGGAACTCTTCCA ICAM-1 Rev primer: 5'-GGTCGATGGCAGGACATAGG ICAM-1 probe: 6FAM-CACCTCAGCCCCCAGGAAGCTCCTAMRA SPUD primers and probe (synthesized by $A B I$ ): SPUD Fwd primer: 5'-AACTTGGCTTTAATGGACCTCCA SPUD Rev primer: 5'-ACATTCATCCTTACATGGCACCA SPUD probe:

6FAM-TGCACAAGCTATGGAACACCACGT-TAMRA. SPUD 101 bp amplicon (sequence from Nolan et al., 2006) (synthesized by IDT for this study):

5'-AACTTGGCTTTAATGGACCTCCAATTTTGAGTGTGCA CAAGCTATGGAACACCACGTAAGACATAAAACGGCCAC ATATGGTGCCATGTAAGGATGAATGT

\section{Preparation of amplicon and plasmid for $q P C R$}

SPUD amplicon dilution. We received $0.07 \mathrm{mg}$ of the 101 bp SPUD amplicon (Nolan et al., 2006) from IDT. Its molar extinction coefficient was listed as $\varepsilon=999100 \mathrm{~L} /(\mathrm{mole} \cdot \mathrm{cm})$, and its $\mathrm{MW}=31,234.3$. The amplicon arrived as a lyophilate and was diluted with $1500 \mu \mathrm{l}$ Ambion TE pH 8.0 to yield a stock solution that was $\sim 9 \times 10^{11}$ amplicons/ $\mu$ l. NanoDrop analysis indicated that the solution was $46.7 \mathrm{ng} / \mu \mathrm{l}$. This sample was diluted to 104,000 amplicons/ $\mu$ l with Ambion nuclease-free water.

SPUD plasmid dilution. We received $0.0058 \mathrm{mg}$ of the 101 bp SPUD amplicon-containing plasmid from IDT. Its MW was given as $1,237,604.8 \mathrm{~g} / \mathrm{mole}$. The plasmid arrived as a lyophilate and was diluted with $40 \mu \mathrm{l}$ Ambion TE pH 8.0 to yield a stock solution that was $\sim 7 \times 10^{10}$ plasmids $/ \mu$ l. NanoDrop analysis indicated that the solution was 144.3 $\mathrm{ng} / \mu \mathrm{l}$. This sample was diluted to 52,000 plasmids $/ \mu \mathrm{l}$ with Ambion nuclease-free water.

(Note: to ensure precision throughout, all pipette volume settings were confirmed for exactness by weighing the amounts of water (at standard temperature and pressure using an analytical scale) delivered by each pipette at each different setting. We have found this quality control measure to be an absolute requirement for all pipette-types; surprisingly, many researchers avoid doing this).

\section{One-step qPCR}

The SPUD amplicon and plasmid stock solutions were prepared for use in qPCR as follows: $104.2 \mu \mathrm{l}$ of $50 \mathrm{mM}$
$\mathrm{MgSO}_{4}$ solution (from the Invitrogen $11745-500 \mathrm{kit}$ ) was added to $20 \mu \mathrm{l}$ of the 104,000 SPUD amplicon/ $\mu$ l solution, and to $20 \mu \mathrm{l}$ of the 52,000 SPUD plasmid/ $\mu$ l solution. 67 $\mu \mathrm{l}$ of these solutions were added to respective master mix amounts prepared for $25 \mu \mathrm{l}$-size reactions for 24 samples (each in duplicate; $50 \mu \mathrm{l}$ total). Final reaction amounts applied to the plate were $20 \mu \mathrm{l}$. Each $20 \mu \mathrm{l}$ reaction (for SPUD amplicon determination) contained $\sim 15,500$ SPUD amplicons, whereas each $20 \mu$ reaction (for SPUD plasmid determination) contained $\sim 7,750$ plasmids (since each plasmid molecule has two copies of SPUD target). Paired target reactions were run for ovine ICAM-1 as a positive qPCR control. The reactions contained either 1) water as sample (for no-template control "NTC" wells) + SPUD amplicon or plasmid, 2) sheep lung standard RNA sample + SPUD amplicon or plasmid, or 3) one of five single sheep lung RNA samples (B, C, F, H or J) + SPUD amplicon or plasmid. Thermocycling was performed on a GeneAmp 5700 $(\mathrm{ABI})$ as follows: $15 \mathrm{~min}$. at $55^{\circ} \mathrm{C}$ (for reverse transcription), 2 min. at $95^{\circ} \mathrm{C}$ for $\mathrm{Taq}$ activation and then 50 cycles of [15 sec. at $95^{\circ} \mathrm{C} ; 30 \mathrm{sec}$. at $60^{\circ} \mathrm{C}$.

\section{Results}

$\mathrm{C}_{\mathrm{q}}$ values were processed using custom Excel files and efficiency-of-amplification (E) values for each target was calculated using the formula: [10 $(-1 / \mathrm{m})-1]$ (Livak et al., 2001). According to standard curves generated for each target, ICAM-1 amplified at an E of $\sim 105.4 \%$ (Figures 1 and 2), the SPUD amplicon amplified at an $E$ of $\sim 80.8 \%$ (Figures 3 and 5 ) and the SPUD plasmid amplified with an E of $\sim 97.85 \%$ (Figures 2 and 5).

All samples spiked with SPUD amplicon prior to cycling appeared around a very tight $C_{q}$ center of $27.387 \pm 0.284$. All samples spiked with the SPUD plasmid prior to cycling appeared around a very tight $C_{q}$ center of $23.823 \pm 0.15$.

The fact that the SPUD amplicon stably amplifies at a significantly lower efficiency than does the SPUD amplicon-containing plasmid, we feel, shines light on a large misconception in qPCR. It is often assumed that the same target sequence, no matter how it is presented in the qPCR, should amplify with the same efficiency. We have never found this to be true in our work. E.g. when we compared endogenous sheep lung VEGF RNA splice variant targets to the same targets contained in plasmids (using both plasmids and sample at non-inhibitory dilutions; as established by PREXCEL-Q), the same target demonstrated a different efficiency of amplification. Since inhibition had been eliminated from these assays, there must be different geometries at work by which the same target, presented to qPCR in different contexts, will amplify at different efficiencies accordingly (J.M. Gallup, A. Van Geelen, unpublished). The differing efficiencies in such cases are thus not due to one target reaction (i.e. for the 101 bp SPUD amplicon) being inhibited while the other (SPUD plasmid) is not, rather, the geometry of target:primer-probe interaction (at the chosen thermocycling conditions) is most likely more optimal for the SPUD plasmid reaction than it is for the SPUD amplicon reaction. That is to say, at the conditions chosen, one reaction's template context is more kinetically-conducive to efficient qPCR than the other, even though the same target is being amplified in both cases. It could be that the SPUD target, when held within the more thermodynamically stable context of a plasmid, is more readily amplified than is the SPUD amplicon itself. 


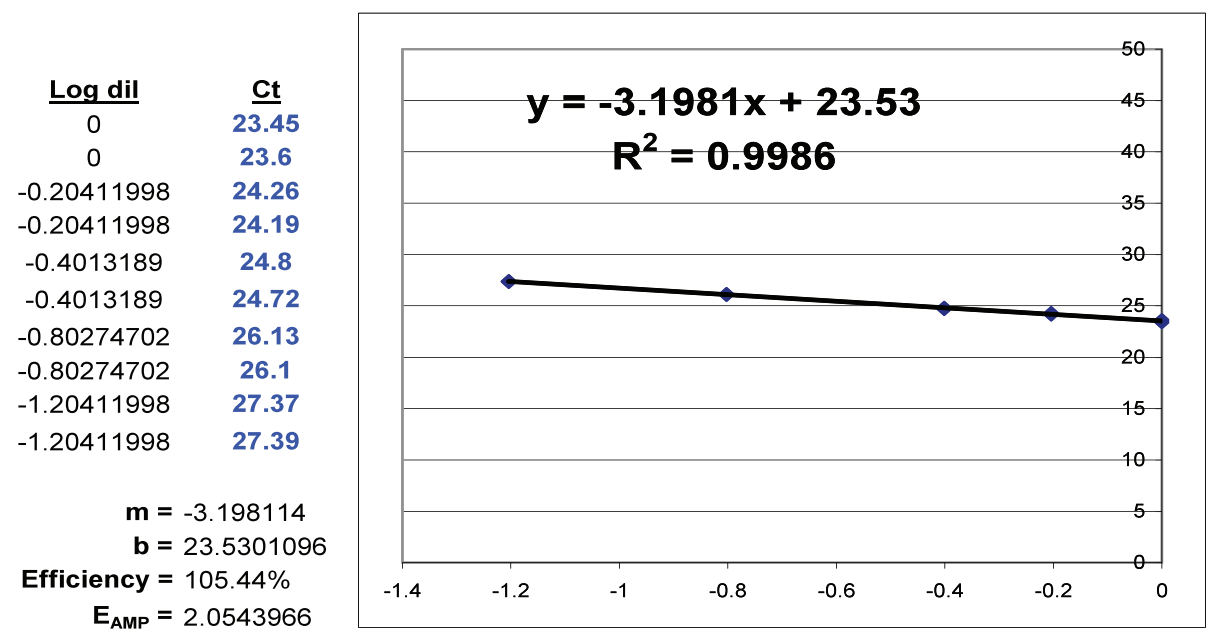

Figure 1. ICAM-1 Standard Curve.

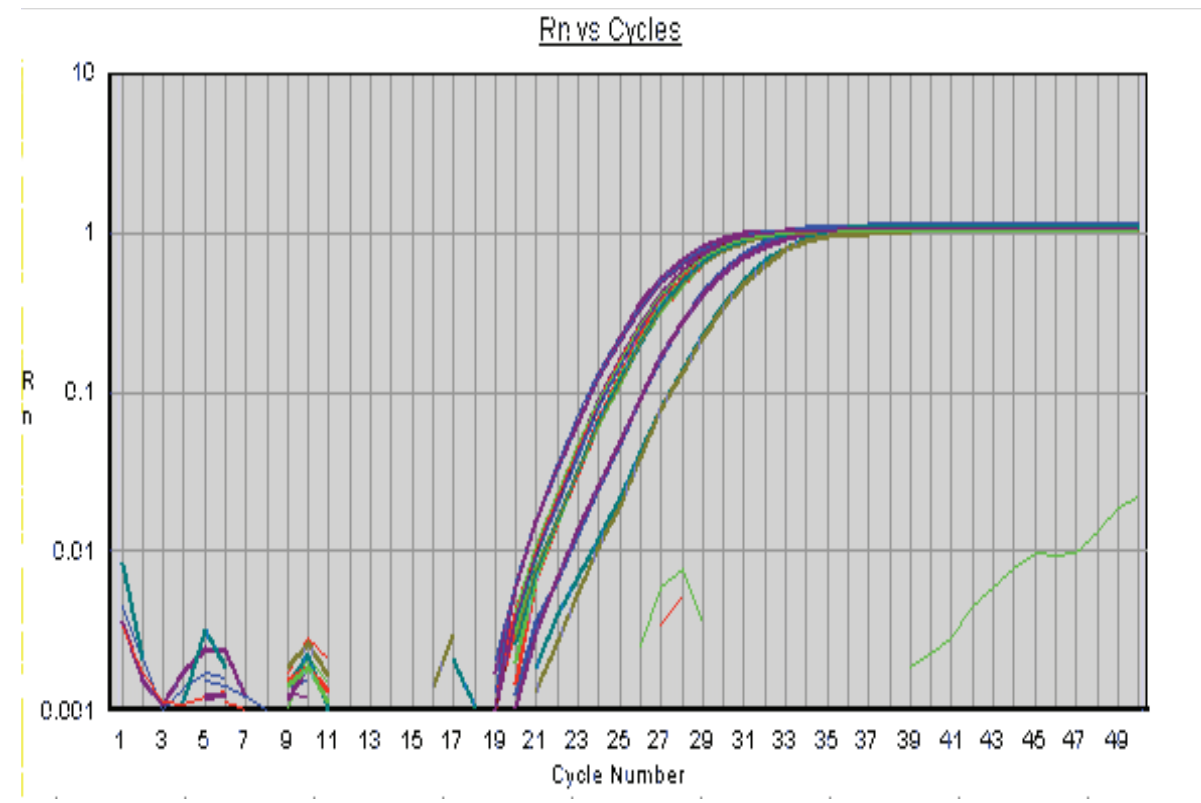

Figure 2. ICAM-1 amplifications.

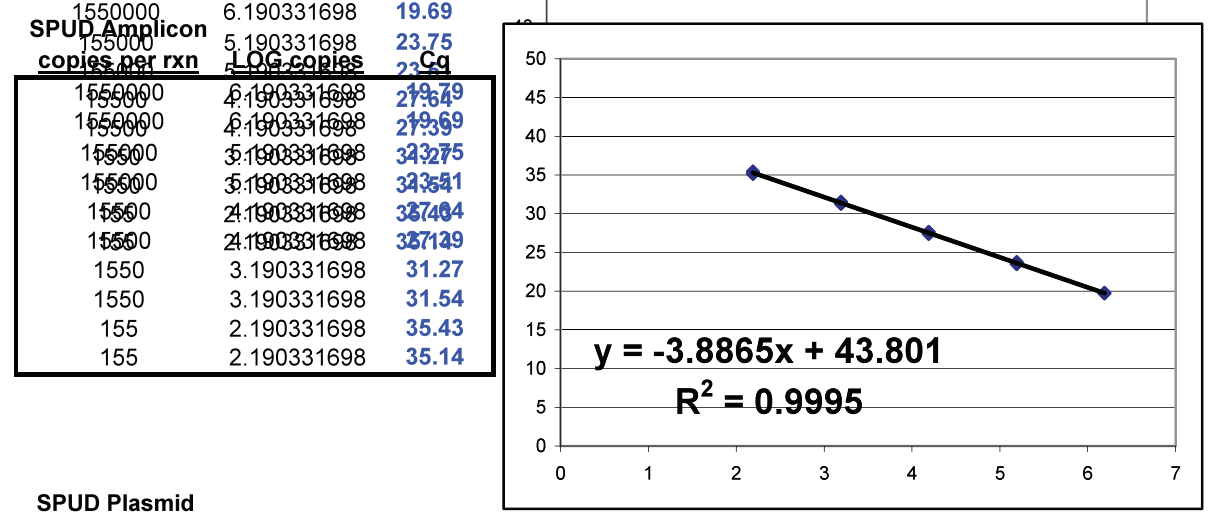

Figure 3. SPUD amplicon standard curve. 


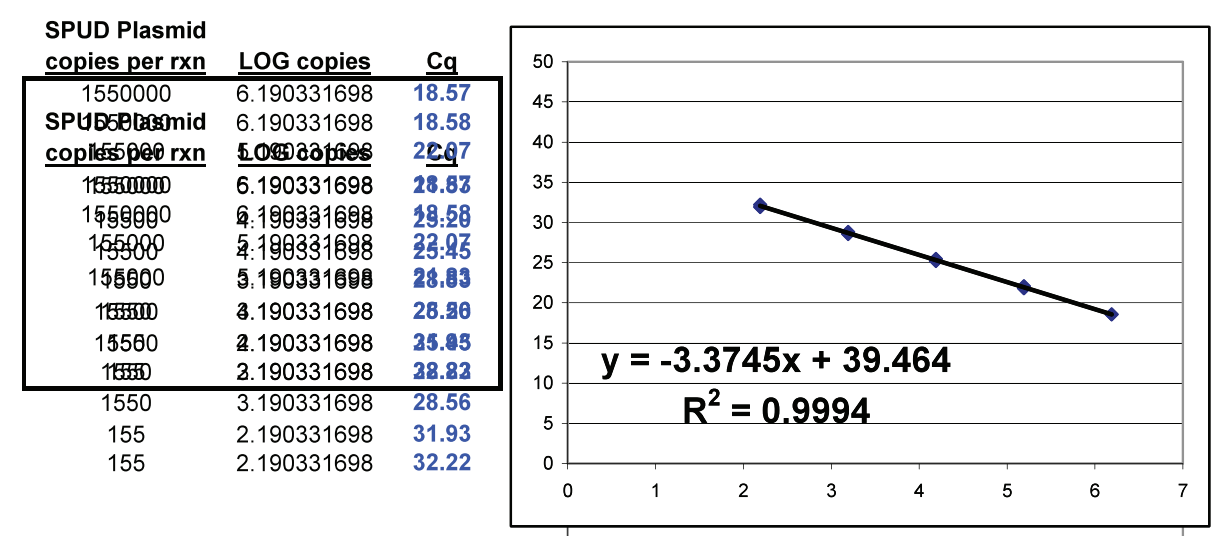

Figure 4. SPUD plasmid standard curve (2 SPUD "copies" per dsDNA plasmid).

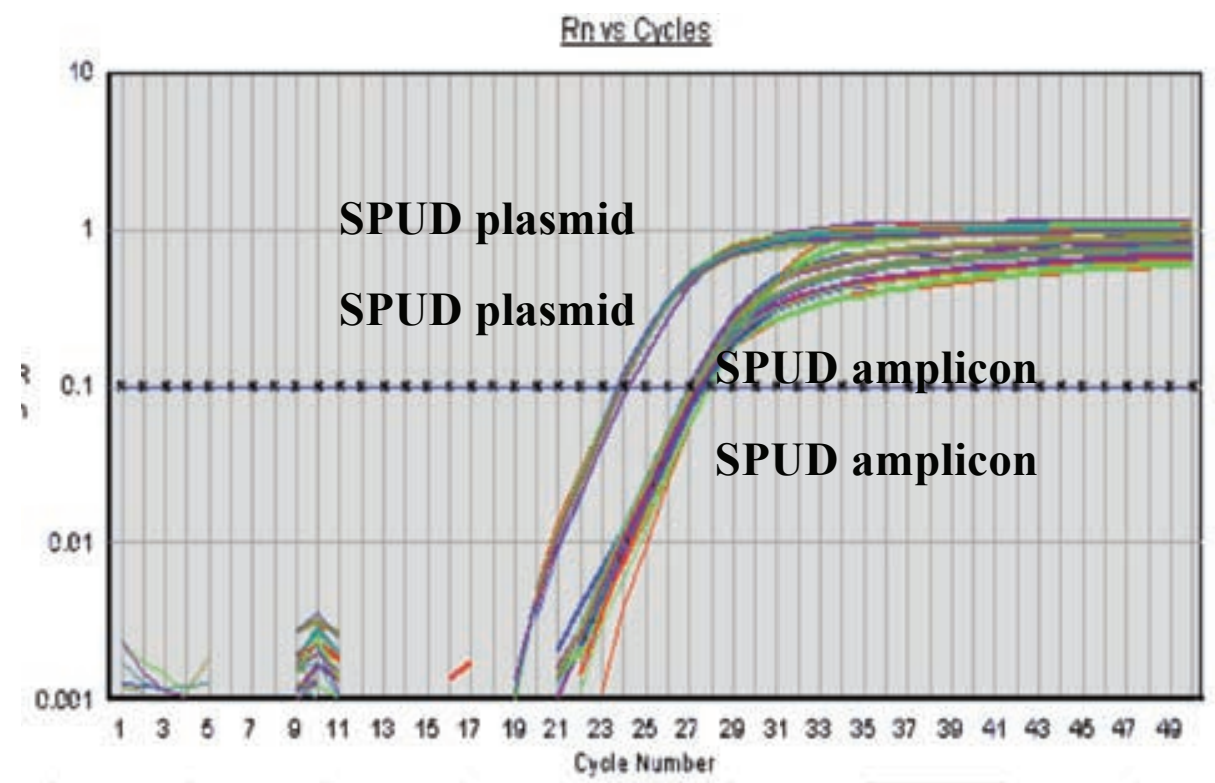

Figure 5. SPUD amplicon and SPUD plasmid amplifications.

An additionally interesting detail which surfaced as a result of this study was the observation that the NTC reactions (for SPUD amplicon and plasmid reactions) yielded $\mathrm{C}_{\mathrm{q}}$ values that were significantly larger than the average of their respective sample-containing target reactions suggesting that the samples, in and of themselves, harbor a slight qPCR-stimulatory characteristic. The average NTC $\mathrm{C}_{\mathrm{q}}$ for the SPUD amplicon was $0.542 \mathrm{C}_{\mathrm{q}}$ units later than all other corresponding reactions spiked equally with SPUD amplicon, and the average NTC $\mathrm{C}_{\mathrm{a}}$ for the SPUD plasmid was $0.426 \mathrm{C}_{\mathrm{q}}$ units later than all other corresponding reactions spiked equally with SPUD plasmid.

In summary, these findings support our claim that PREXCEL-Q-calculated nucleic acid sample and standard dilutions for qPCR, based on the "Stock I approach" (Grubor et al., 2004; Gallup et al., 2005; Gallup et al., 2006; Kawashima et al., 2006; Lazic et al., 2007; Gallup et al., 2008; Olivier et al., 2009; Sow et al., 2009; Sponseller et al.,
2009), avoids GPCR inhibitory behavior in all final reactions (Gallup et al., 2008; Sow et al., 2009). Because of this and other aspects, we recommend the use of PREXCEL-Q in all laboratories performing $\mathrm{QPCR}$ of any kind.

\section{Acknowledgements}

This work was supported by NIIAD NIHRO1062787. The authors would like to thank Dr. Suzanne Kennedy of MO BIO Laboratories for suggestions and editing this publication, colleagues, Dr. Tanja Lazic, Dr. Alicia K. Olivier, Dr. Rachel J. Derscheid and Bryan J. Anderson for their critical, technical support throughout this and many other qPCR endeavors. We also wish to express our on-going appreciation to Nancy Hanna and Mary E. Hull for their continuing help with the orders placed for all of our research endeavors. And particular thanks to Jeff M. Gallup for inspiring our continual involvement with qPCR. 


\section{References}

Bustin, S.A. (2003). A-Z of Quantitative PCR (La Jolla, CA: International University Line, Biotechnology Series).

Bustin, S.A. (2005). Real-time, Fluorescence-based quantitative PCR: a snapshot of current procedures and preferences. Expert Rev. Mol. Diagn. 5, 493-498.

Bustin, S.A. (2008). Real-time polymerase chain reaction - towards a more reliable, accurate and relevant assay. Eur. Pharm. Rev. 6, 19-27.

Bustin, S.A. (2008). Real-time quantitative PCR opportunities and pitfalls. Eur. Pharm. Rev. 4, 18-23.

Bustin, S.A., and Nolan, T. (2009). Analysis of mRNA Expression by Real-time PCR. In Real-time PCR: Current Technology and Applications, Logan, J., Edwards, K., and Saunders, N., ed. (Norfolk, UK: Caister Academic Press), pp. 111-135.

Bustin, S.A., Benes, V., Garson, J.A., Hellemans, J., Huggett, J., Kubista, M., Mueller, R., Nolan, T., Pfaffl, M.W., Shipley, G.L., Vandesompele, J., and Wittwer, C.T. (2009). The MIQE Guidelines: Minimum Information for Publication of Quantitative Real-Time PCR Experiments. Clin. Chem. 55, 611-622.

Gallup, J.M., Kawashima, K., Lucero, G., and Ackermann, M.R. (2005). New quick method for isolating RNA from laser captured cells stained by immunofluorescent immunohistochemistry; RNA suitable for direct use in fluorogenic TaqMan one-step real-time RT-PCR. Biol. Proced. Online. 7, 70-92.

Gallup, J.M., and Ackermann, M.R. (2006). Addressing fluorogenic real-time qPCR inhibition using the novel custom Excel file system 'FocusField2-6GallupqPCRSetupTool-001' to attain consistently high fidelity qPCR reactions. Biol. Proced. Online. 8, 87-155.

Gallup, J.M., and Ackermann, M.R. (2008). The 'PREXCEL-Q Method' for qPCR. Int. J. Biomed. Sci. 4, 273-293.

Grubor, B.M., Gallup, J.M., Meyerholz, D.K., Crouch, E.C., Evans, R.B., Brogden, K.A., Lehmkuhl, H.D., and Ackermann, M.R. (2004). Enhanced surfactant protein and defensin mRNA levels and reduced viral replication during parainfluenza virus type 3 pneumonia in neonatal lambs. Clin. Diag. Lab. Immunol. 11, 599-607.

Kawashima, K., Meyerholz, D.K., Gallup, J.M., Grubor, B., Lazic, T., Lehmkuhl, H.D., and Ackermann, M.R. (2006). Differential expression of ovine innate immune genes by preterm and neonatal lung epithelia infected with respiratory syncytial virus. Viral Immunol. 19, 316-323.
Lazic, T., Wyatt, T.A., Matic, M., Meyerholz, D.K., Grubor, B., Gallup, J.M., Kersting, K.W., Imerman, P.M., AlmeidaDe-Macedo, M., and Ackermann, M.R. (2007). Maternal alcohol ingestion reduces surfactant protein A expression by preterm fetal lung epithelia. Alcohol 41, 347-355.

Livak, K.J., and Schmittgen, T.D. (2001). Analysis of Relative Gene Expression Data Using Real-Time Quantitative PCR and the $2^{-\triangle \Delta C T}$ Method. Methods 25, 402-408. doi:10.1006/ meth.2001.1262.

Nolan, T., Hands, R.E., and Bustin, S.A. (2006). Quantification of mRNA using real-time RT-PCR. Nat. Prot. 1, 1559-1582.

Nolan, T., Hands, R.E., Ogunkolade, B.W., and Bustin, S.A. (2006). SPUD: a qPCR assay for the detection of inhibitors in nucleic acid preparations. Anal. Biochem. 351, 308-310.

Nolan, T., and Bustin, S.A. (2009). The importance of sample quality for qPCR. Eur. Pharm. Rev. 1, Article 1.

Olivier, A., Gallup, J., de Macedo, M.M.M.A, Varga, S.M., and Ackermann, M. (2009). Human respiratory syncytial virus A2 strain replicates and induces innate immune responses by respiratory epithelia of neonatal lambs. Int. J. Exp. Path. 90, 431-438.

Sow, F.B., Gallup, J.M., Meyerholz, D.K., and Ackermann, M.R. (2009). Gene profiling studies in the neonatal ovine lung show enhancing effects of VEGF on the immune response. Dev. Comp. Immunol. 33, 761-771.

Sow, F.B., Gallup, J.M., Sacco, R.E., and Ackermann, M.R. (2009). Laser Capture Microdissection Revisited as a Tool for Transcriptomic Analysis: Application of an ExcelBased qPCR Preparation Software (PREXCEL-Q). Int. J. Biomed. Sci. 5, 105-124.

Sponseller, B.A., de Macedo, M.M., Clark, S.K., Gallup, J.M., and Jones, D.E. (2009). Activation of peripheral blood monocytes results in more robust production of IL-10 in neonatal foals compared to adult horses. Vet. Immunol. Immunopathol. 127, 167-173.

Tichopad, A., Pfaffl, M.W., and Didier, A. (2003). Tissuespecific expression pattern of bovine prion: quantification using real-time RT-PCR. Molecular Cellular Probes 17, 5-10.

Tichopad, A., Didier, A., and Pfaffl, M.W. (2004). Inhibition of real-time RT-PCR quantification due to tissue specific contaminants. Molecular Cellular Probes 18, 45-50.

Wilson, I.G. (1997). MINIREVIEW: Inhibition and Facilitation of Nucleic Acid Amplification. Appl. Env. Microb. 63, 3741-3751. 


\section{Further Reading}

Caister Academic Press is a leading academic publisher of advanced texts in microbiology, molecular biology and medical research. Full details of all our publications at caister.com

- MALDI-TOF Mass Spectrometry in Microbiology Edited by: M Kostrzewa, S Schubert (2016) www.caister.com/malditof

- Aspergillus and Penicillium in the Post-genomic Era Edited by: RP Vries, IB Gelber, MR Andersen (2016) www.caister.com/aspergillus2

- The Bacteriocins: Current Knowledge and Future Prospects Edited by: RL Dorit, SM Roy, MA Riley (2016)

www.caister.com/bacteriocins

- Omics in Plant Disease Resistance Edited by: V Bhadauria (2016) www.caister.com/opd

- Acidophiles: Life in Extremely Acidic Environments Edited by: R Quatrini, DB Johnson (2016) www.caister.com/acidophiles

- Climate Change and Microbial Ecology: Current Research and Future Trend

Edited by: J Marxsen (2016)

www.caister.com/climate

- Biofilms in Bioremediation: Current Research and Emerging Technologies

Edited by: G Lear (2016)

www.caister.com/biorem

- Microalgae: Current Research and Applications Edited by: MN Tsaloglou (2016) www.caister.com/microalgae

- Gas Plasma Sterilization in Microbiology: Theory, Applications, Pitfalls and New Perspectives Edited by: H Shintani, A Sakudo (2016) www.caister.com/gasplasma

- Virus Evolution: Current Research and Future Directions Edited by: SC Weaver, M Denison, M Roossinck, et al. (2016) www.caister.com/virusevol

- Arboviruses: Molecular Biology, Evolution and Control Edited by: N Vasilakis, DJ Gubler (2016) www.caister.com/arbo

- Shigella: Molecular and Cellular Biology Edited by: WD Picking, WL Picking (2016) www.caister.com/shigella

-Aquatic Biofilms: Ecology, Water Quality and Wastewater Treatment

Edited by: AM Romaní, H Guasch, MD Balaguer (2016)

www.caister.com/aquaticbiofilms

- Alphaviruses: Current Biology

Edited by: S Mahalingam, L Herrero, B Herring (2016)

www.caister.com/alpha

- Thermophilic Microorganisms

Edited by: F Li (2015)

www.caister.com/thermophile
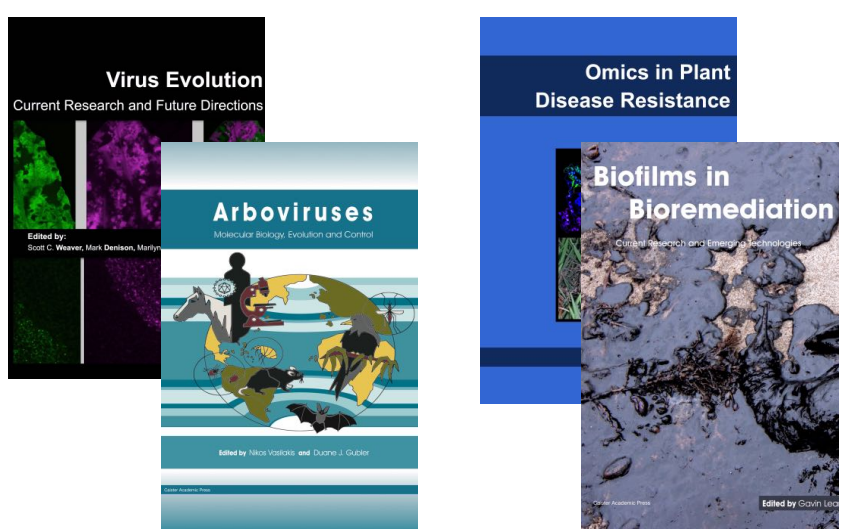
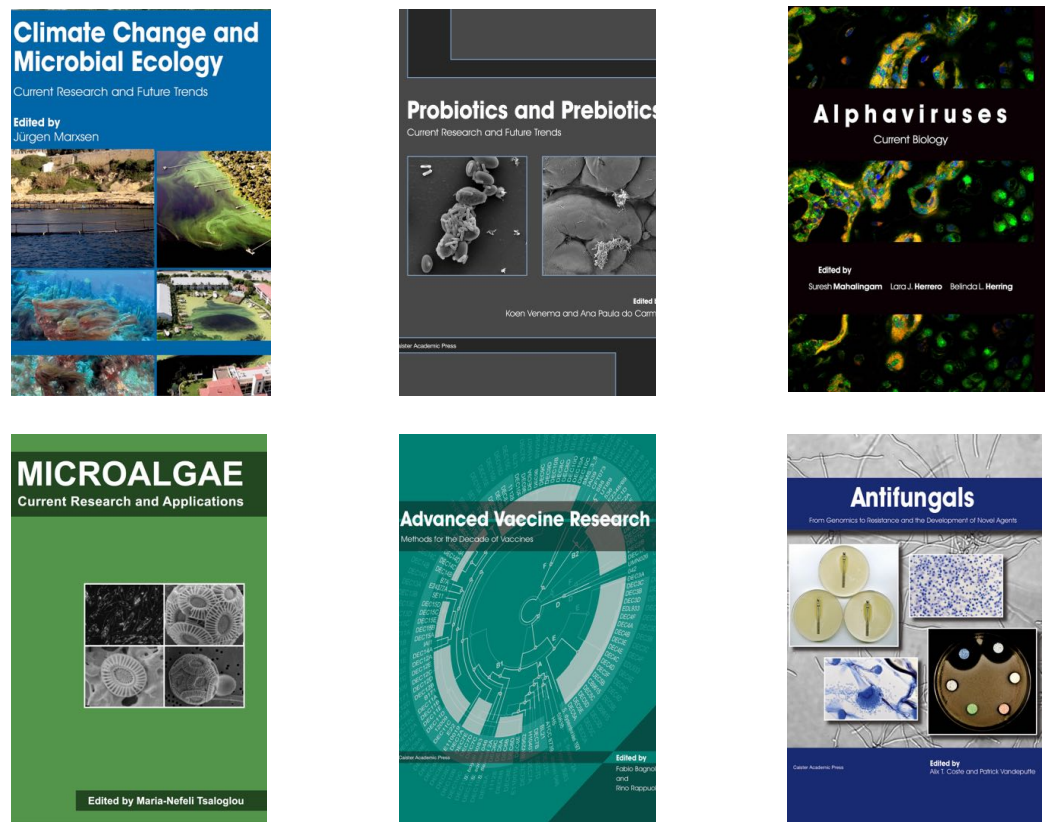

- Flow Cytometry in Microbiology: Technology and Applications Edited by: MG Wilkinson (2015) www.caister.com/flow

- Probiotics and Prebiotics: Current Research and Future Trends Edited by: K Venema, AP Carmo (2015) www.caister.com/probiotics

- Epigenetics: Current Research and Emerging Trends Edited by: BP Chadwick (2015) www.caister.com/epigenetics2015

- Corynebacterium glutamicum: From Systems Biology to Biotechnological Applications

Edited by: A Burkovski (2015)

www.caister.com/cory2

- Advanced Vaccine Research Methods for the Decade of Vaccines

Edited by: F Bagnoli, R Rappuoli (2015)

www.caister.com/vaccines

- Antifungals: From Genomics to Resistance and the Development of Novel Agents

Edited by: AT Coste, P Vandeputte (2015)

www.caister.com/antifungals

- Bacteria-Plant Interactions: Advanced Research and Future Trends Edited by: J Murillo, BA Vinatzer, RW Jackson, et al. (2015) www.caister.com/bacteria-plant

\section{- Aeromonas}

Edited by: J Graf (2015)

www.caister.com/aeromonas

- Antibiotics: Current Innovations and Future Trends

Edited by: S Sánchez, AL Demain (2015)

www.caister.com/antibiotics

- Leishmania: Current Biology and Contro Edited by: S Adak, R Datta (2015) www.caister.com/leish2

- Acanthamoeba: Biology and Pathogenesis (2nd edition) Author: NA Khan (2015)

www.caister.com/acanthamoeba2

- Microarrays: Current Technology, Innovations and Applications Edited by: Z He (2014)

www.caister.com/microarrays2

- Metagenomics of the Microbial Nitrogen Cycle: Theory, Methods and Applications

Edited by: D Marco (2014)

www.caister.com/n2 